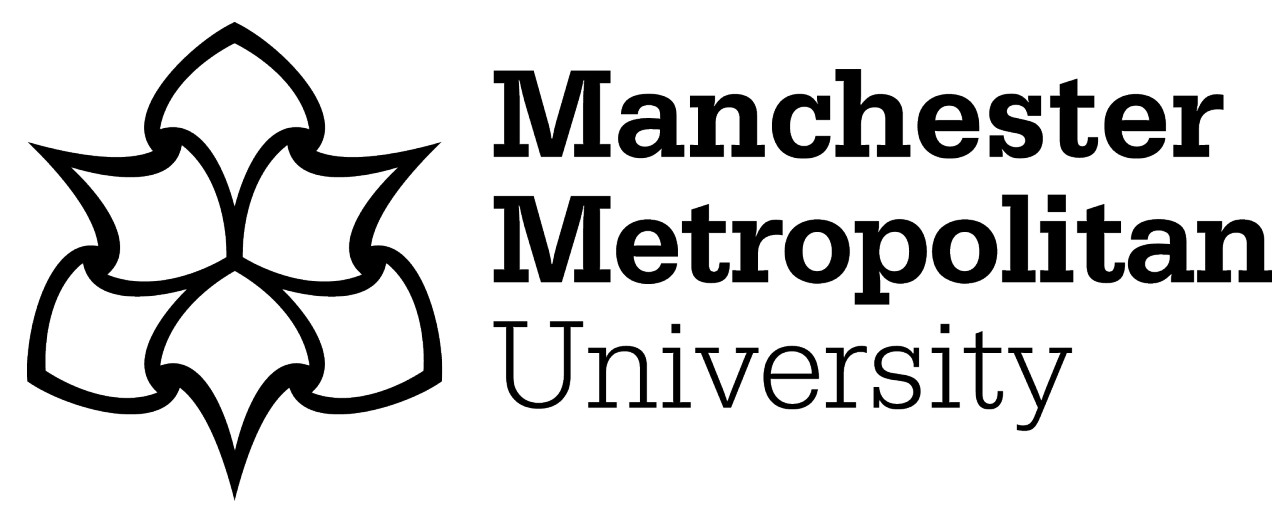

Fisher, Jenny and Yarwood, Gemma (2008) Connecting not competing with others: raising awareness of wellbeing. Journal of the Royal Society for the Promotion of Health, 128 (3). pp. 110-111. ISSN 1466-4240

Downloaded from: https://e-space.mmu.ac.uk/30000/

Version: Accepted Version

Publisher: Sage Publications Ltd.

DOI: https://doi.org/10.1177/1466424008089802

Please cite the published version 


\section{Connecting not competing with others- raising awareness of wellbeing}

The public health benefits of social capital have long been recognised and debated. Countless articles and policy statements have been published that help develop and support existing knowledge or challenge accepted beliefs regarding social support and mental health ${ }^{1,2}$. Increasing the population's happiness levels is a key challenge for Government ${ }^{3,4}$ as is developing preventative health measures aimed at reducing unhealthy lifestyles ${ }^{5}$. However a paradox exists in terms of communicating health messages with the aim of improving wellbeing and what we in western societies value and believe increases our happiness. This article aims to provide potential consideration of these issues.

Recent work of psychologist and write Oliver James ${ }^{6}$ focuses on the concept of Affluenza, defined as placing a high value on money, possessions, appearance and fame. James argues that the 'virus' is driving 'English-speaking nations' in particular towards mental illhealth in alarming numbers. Ideas about affluenza appear to be wrapped up in concerns about the competitive nature of individuals and the age old adage of 'keeping up with the Jones'. The capitalist self-serving consumerist culture that drives many individuals to define their happiness and worth by commodities and status has been blamed for the rise in mental ill health. Perhaps this could be considered a rather simplistic link between the rise in mental illness and consumerist culture. However, it would be foolhardy to overlook how these messages have been communicated, how they have evolved and the role recent research into the values of social networking can play in improving the communication of health messages.

From a glance at women's magazines, popular websites and the newspapers it appears that individuals are gripped by a preoccupation of improving their happiness. In James' 6 view, societies based on selfish capitalism communicate their health messages by grooming, nurturing and feeding these needy individuals and their hopes for a quick fix of happiness. For many, owning a larger plasma television that the neighbours or shopping at Waltrose instead of Aldi increases happiness ${ }^{7}$ but for how long does the feeling last ? Until the neighbours buy an even bigger television or the food is consumed or discarded ? Increasing credit card debts show that we are consuming more and more but it is well documented that the more we spend does not make us happier or improve our well-being. ${ }^{8}$ The New Economics Foundation also document that our outlook on life and the activities and friendships we are involved in are $40 \%$ responsible for influencing our wellbeing ${ }^{8}$. 
The contested term 'wellbeing' concerns individuals making decisions regarding a plethora of lifestyle aspects including diet, fitness, sexual health, our relationships, working loves, the communities we live in and the environment we share. Public health messages should indeed encourage and motivate individuals to be wellbeing aware. However what is omitted from the communication is that changing lives for the better and improving mental health does not mean competing with each other for the latest 'must-have' but connecting and supporting one another and exploiting the value of social capital. Improving wellbeing does not necessarily mean turning your life upside down and feeling under pressure to transform, but focusing on small steps to improvement and utilising and valuing what you already have. Evidence has shown that the informal networks and friendships that people connect with improve their wellbeing ${ }^{9}$ and Webster puts forward 'good relationships and self-esteem as being of crucial importance to human health and wellbeing. ${ }^{10} \mathrm{~A}$ chat in the post office queue, going to the cinema with a friend, reading a book or catching up with old friends online can vastly improve happiness levels yet they are habitually overlooked as meaningful to our wellbeing ${ }^{11}$. Although the ' 5 - $a$-day' campaign ${ }^{12}$ demonstrates extending life as recent research has shown ${ }^{13}$ this needs to work symbiotically with other messages that convey the mental health benefits of social networks (both virtual and non-virtual) and casual encounters.

Guilt itself has become an advertising marketing vehicle further reinforcing notions of the selfish capitalist. In preserving western society's fixation with the pursuit of personal happiness, there is a heightened sense of guilt when individuals don't succeed at an impossible state of continual happiness, satisfaction and perfection ${ }^{14}$. Public health messages concerning obesity, smoking and lack of exercise can also compound and exploit individuals' feelings of guilt. We need to move on to a new means of communicating public health messages that focus on celebrating what we have and enjoying the here and now. Further communication needs to address the fact that material gains do not bring long term happiness or wellbeing and can compound the mental health issues of individuals and indeed the population ${ }^{6}$.

In one of his first speeches of 2008, Gordon Brown stated that he intends to focus on preventative health measures ${ }^{15}$, Accordingly commentators have noted that this presents a challenge for the government to address changing social behaviour with regard our consumption ${ }^{13}$. We would strongly agree with this but it is not going to be straightforward given the contemporary capitalist consumerist society and the dearth of public health messages conveying the value of friendships and social activities. 
Gemma Yarwood - Senior Lecturer

Department of Psychology and Social Change

Manchester Metropolitan University

1. Health Development Agency. Social Capital for Health - Insights from Qualitative Research. London: Health Development Agency, 2002

2. Harpham T, and McKenzie K. Social Capital and Mental Health. London: Jessica Kinsgley Publishers, 2006

3. Layard R. Happiness - Lessons from a New Science. London: Penguin Books, 2005

4. Walker D. Happy Talk The Guardian. 2007: Jul 3

5. Giddens A. Over To You Mr Brown. Cambridge: Polity Press, 2007

6. James O. Affluenza - How to be Successful and Stay San. London: Vermilion, 2007

7. New Woman. 2008; Jan

8. New Economics Foundation, A Wellbeing Manifesto for a Flourishing Society. London: New Economics Foundation, 2004

9. Bowen GL, Mancini JA, Marcini JA, and Nelson JP, Community Capacity: Antecedents and Consequences. Journal of Community Practice 2008; 8: 2 -21

10.Webster A, Wellbeing. London: SCM Press, 2002

11.Morrison B, The Power of Healing. The Guardian 2007 Jan 5

12.5 a day campaign available at: http://www.5aday.nhs.uk

13.The Independent, There is only one real way to improve public health. The Independent 2008 Jan 8

14.Bunting M, The Big Question. The Guardian 2008 Jan 5

15.Brown G, Speech on the National Health Service; 2008 Jan 7; London. Available from: 10 Downing Street http://www.number10.gov.uk/output/Page14171.asp 